\title{
Origin of elevated PGE contents and Pt/Pd in Bushveld magmas: constraints from $W$ and $R u$ isotopes
}

\author{
W.D. Maier ${ }^{1 *}$, A. Mundl-Petermeier ${ }^{2}$ \\ ${ }^{1}$ School of Earth and Environmental Sciences, Cardiff University, UK \\ ${ }^{2}$ Department of Lithospheric Research, University of Vienna, Austria \\ *Corresponding author e-mail: maierw@cardiff.ac.uk
}

Summary Bushveld magmas have unusually high PGE contents and Pt/Pd ratios. This could be due to melting of PGE rich mantle containing undissolved Late Veneer. However, the available $\mathrm{W}$ and $\mathrm{Ru}$ isotope data suggest the Bushveld magmas are derived from normal mantle

\section{Introduction}

The Bushveld Complex hosts the bulk of global PGE resources. Despite of a century of research, the petrogenesis of the PGE reefs, in the Bushveld and elsewhere, remains controversial. In part, this is because for most layered intrusions, the nature of the parent magmas is unknown. The Bushveld Complex is an exception in that it is underlain by a suite of fine-grained sills that are considered to represent the parent magmas. Notably, compared to global mafic-ultramafic magmas, the Bushveld magmas are unusual, in being dominated by $\mathrm{Pt}$, whereas most global magmas are Pd dominated (e.g., Naldrett 2004; Maier and Barnes 2004). The specific reasons for this variation remain under debate. An improved understanding is important for exploration and mining as $\mathrm{Pd}$ is currently twice as valuable as $\mathrm{Pt}(\sim 2000$ \$poz vs $\sim 1000$ \$poz, http://www.platinum.matthey.com). Also, understanding the PGE variation can place added constraints on petrogenetic models for layered intrusions and on the compositional evolution of the Earth's mantle. In the present paper, we will examine the possibility that the elevated PGE contents and $\mathrm{Pt} / \mathrm{Pd}$ ratios result from melting of mantle domains that contain incompletely dissolved late veneer.

\section{Research questions at hand}

The PGE contents of the Earth's modern mantle are largely the result of processes occurring during the Hadean and Archean eras. (i) The vast bulk of the Earth accreted $4.5 \mathrm{Ga}$ ago from impactors that remain incompletely known and appear not to be represented in our meteorite collections (Fischer-Goedde et al. 2020). (ii) Next, the Earth's core formed via segregation of Fe-Ni alloy (and some sulfide) at $<70 \mathrm{Ma}$ after Earth's initial accretion. The segregation of the core resulted in efficient scavenging of the highly siderophile and chalcophile PGE and Au from the Earth's mantle. (iii) The mantle was refertilised with PGE and Au by late accretion (Late Veneer) of impactors from $\sim 4.5 \mathrm{Ga}$ to $\sim 3.8 \mathrm{Ga}$, including a final surge (the late heavy bombardment, LHB) at ca $3.8 \mathrm{Ga}$. Based on PGE systematics it is estimated that the LV added $\sim 0.5 \%$ to the mass of the Earth (Fischer Goedde et al. 2020). The most important impactors were likely carbonaceous chondrites (Fischer Goedde et al. 2020) which tend to have $\sim 0.9-1.2$ ppm Pt and 0.6-0.8 ppm Pd, i.e., they have Pt/Pd significantly above unity (Fischer Goedde et al. 2011, Horan et al. 2013, Day et al. 2016). Other potential impactors include iron meteorites representing the cores of asteroids and planets. These have markedly higher $\mathrm{Pt}$ (up to $>30 \mathrm{ppm}$ ) and Pt/Pd ( 3-20)(Day et al. 2016) than chondrites. The rate of mixing and equilibration of the Late Veneer into the convecting mantle remains debated: Maier et al. (2009) suggested a timespan of ca $1.5 \mathrm{Ga}$ (i.e. until $\sim 3 \mathrm{Ga}$ ) based on PGE contents in komatiites, whereas Puchtel 
et al. (2020) suggested that portions of the mantle remained poorly equilibrated with LV until $\sim 2 \mathrm{Ga}$, based on $\mathrm{W}$ and Pt isotopes as well as PGE systematics in komatiites of the Lapland Greenstone belt. Heterogenous inmixing of late veneer is consistent with models of modern mantle dynamics; For example, Barry et al. (2017) showed that whole-mantle convection may preserve long-term global patterns of upper mantle geochemistry. Based on these data one could suggest that the Pt-rich Bushveld magmas formed from a mantle that was relatively enriched in late veneer.

The idea is potentially testable using $\mathrm{W}$ isotopes: $\mu^{182} \mathrm{~W}$ in terrestrial reservoirs shows considerable variation, with Earth's core being less radiogenic $\left(\mu^{182} \mathrm{~W}=-220\right)$ than bulk Earth $(\mu 182 \mathrm{~W}=-200)$, bulk silicate Earth and most terrestrial rocks $\left(\mu^{182} \mathrm{~W}=0\right)$ (Fig. 1) (Walker 2016 and references therein, Mundl et al. 2017). The assumption is that during Hadean core formation most of the Earth's Hf remained in the mantle due to the incompatibility of Hf with regard to $\mathrm{Fe}-\mathrm{Ni}$ alloy. Thus, little ${ }^{182} \mathrm{~W}$ could be produced via radiogenic decay of ${ }^{182} \mathrm{Hf}$ in the core, resulting in relatively low ${ }^{182} \mathrm{~W} /{ }^{184} \mathrm{~W}$. In contrast, the Hadean mantle became enriched in the ${ }^{182} \mathrm{~W}$, the daughter isotope of ${ }^{182} \mathrm{Hf}$. The relative enrichment of the Hadean (and early Archean) mantle in ${ }^{182} \mathrm{~W}$ is reflected in high $\mu^{182} \mathrm{~W}$ of early-mid Archean lavas and cumulates (Tusch et al. 2021). It is further assumed that prior to late accretion, the early Earth's mantle was about $25-30 \mathrm{ppm}$ more radiogenic in terms of $\mu^{182} \mathrm{~W}$ than it is now. Late accretion of largely chondritic material $\left(\mu^{182} \mathrm{~W}=\sim 200\right)$ shifted the tungsten isotopic composition of the mantle by about 25 $30 \mathrm{ppm}$, to result in the present value of $\mu^{182} \mathrm{~W}=0$. The near-zero $\mu^{182} \mathrm{~W}$ of most post Archean rocks is thus normally interpreted to result from partial melting of mantle refertilised with LV, whereas the higher $\mu^{182} \mathrm{~W}$ of the older rocks is interpreted to reflect melting of mantle that had failed to equilibrate with LV. One could further suggest that portions of the mantle containing a relatively high component of LV would be expected to have even lower $\mu^{182} \mathrm{~W}$ than bulk silicate earth.

We attempted to test whether this model could apply to Bushveld by analysing a sample of komatiitic chilled margin (sample 774.11 of Maier et al. 2016). This yielded $\mu^{182} \mathrm{~W}+2.1 \pm 3.6$, possibly suggesting the sample comes from broadly normal mantle without LV enriched or depleted domains. ITE systematics suggest that the sample has undergone some preemplacement and syn-emplacement contamination (Maier et al. 2016). The contaminants could have had high $\mathrm{W}$ contents and high $\mu^{182} \mathrm{~W}$, thereby potentially altering an originally negative $\mu^{182} \mathrm{~W}$ signature. In addition, the relatively high $\mathrm{W} / \mathrm{Th}$ ratio of $\sim 1-2$ suggests that the rock could have been affected by percolation of a W-rich volatile phase. Nevertheless, we currently do not think the data is supportive of an enhanced LV component in the Bushveld mantle source as this should have resulted in elevated $\mathrm{Pd}$ in addition to high $\mathrm{Pt}$, whereas the analysed sample has $\mathrm{Pd}$ content in the range of other Bushveld magmas and typical global komatiites ( $\sim 10 \mathrm{ppb})$. $\mathrm{Pd}$ loss via syn-or late-magmatic devolatisation of the Bushveld magmas can likely be ruled out because this process should also have resulted in significant S loss (Pd would otherwise remain locked in sulfides), yet $\mathrm{S} / \mathrm{Se}$ of the Bushveld magmas is mantle-like (Barnes et al. 2009). On the other hand, if the Bushveld source contained a component of unequilibrated iron meteorite which has much higher Pt/Pd than chondrites (Day et al. 2016), the above arguments based on Pd content would be invalid. Also, an iron meteoritic component in the Bushveld source could possibly explain the elevated $\mathrm{Rh}$ in the Bushveld magmas relative to global magmas (Barnes et al. 2015).

Another tool that could be used to evaluate the presence of mantle domains in the Bushveld source is nucleosynthetic Ru isotopes (Fig. 1). Fischer Goedde et al. (2020) have established that the early (pre-LV) Earth had positive $\varepsilon^{100} \mathrm{Ru}$. The authors applied mass balance to argue that the late veneer must have had negative $\varepsilon^{100} \mathrm{Ru}$ and that efficient mixing of this $\mathrm{LV}$ with the Hadean mantle resulted in $\varepsilon^{100} \mathrm{Ru}=0$ (i.e., the value of bulk silicate Earth). Magmas 
derived from hypothetical LV enriched mantle domains should thus have negative $\varepsilon^{100} \mathrm{Ru}$. Preliminary data of Fischer-Goedde et al. (2020) indicate that some Bushveld UG2 chromitite samples show slightly lower values than other post Archean rocks, although the average value of the UG2 chromitite overlaps with the modern mantle estimate.

We conclude that the currently available data provide no support for the idea that the Bushveld was sourced from LV enriched mantle. However, the amount of data generated so far is very small and more work is clearly needed.

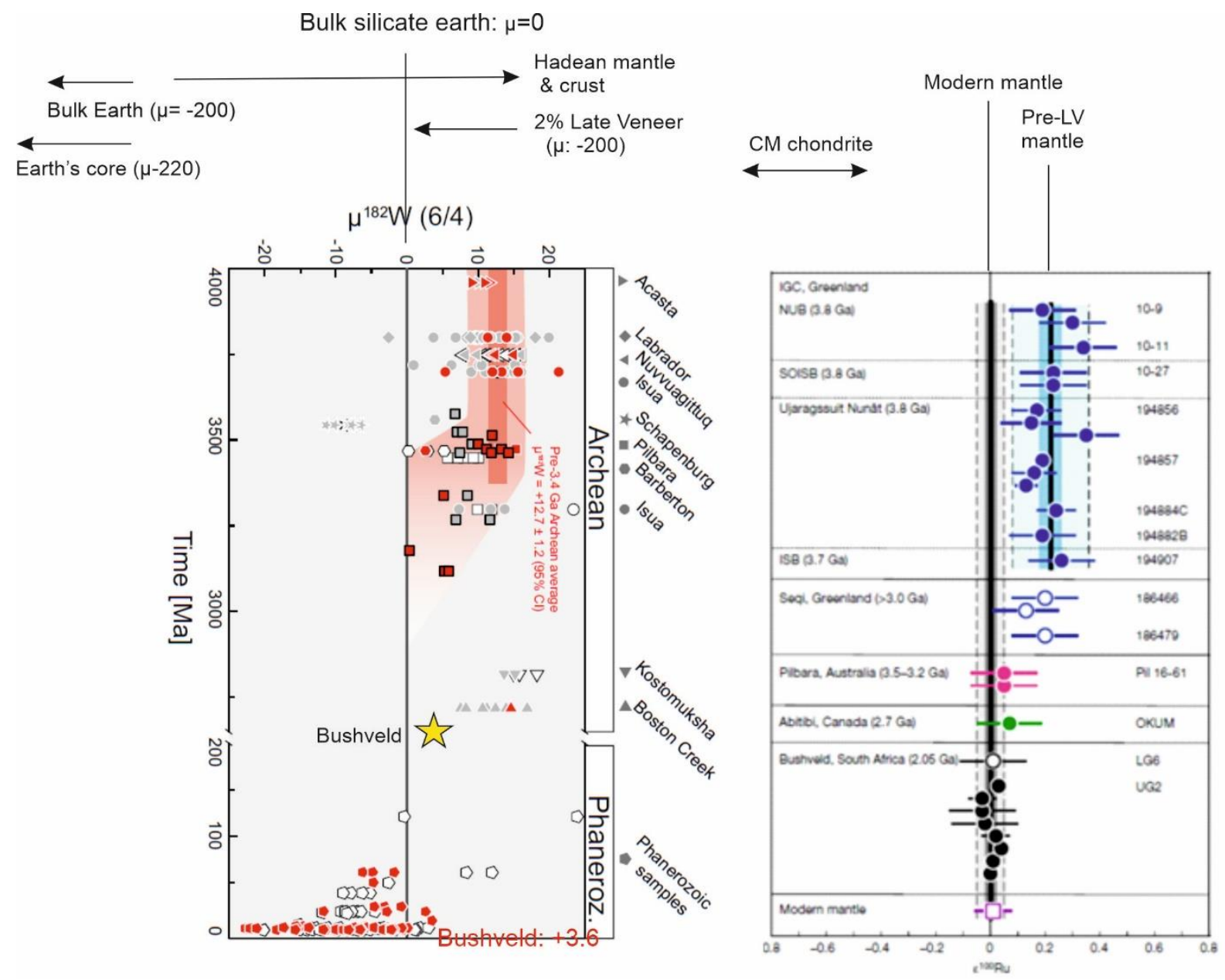

Figure 1. $\mathrm{W}$ and $\mathrm{Ru}$ isotope signatures of Bushveld rocks, compared to other lavas, cumulates, and mantle reservoirs. (A) Modified after Tusch et al. (2021). (B) Adapted from Fischer-Goedde et al. (2020).

\section{Acknowledgements}

Richard Walker (University of Maryland) is thanked for discussion and feedback.

\section{References:}

Barnes Sarah-Jane, Savard D, Bédard LP, Maier WD (2009) Selenium and sulfur concentrations in the Bushveld Complex of South Africa and implications for formation of the platinum-group element deposits. Mineralium Deposita, 44(6), pp.647-663.

Barnes Stephen J, Mungall JE, Maier WD (2015) Platinum group elements in mantle melts and mantle samples, Lithos 232, p 395-417 
Barry TL, Davies JH, Wolstencroft M, Millar IL, Zhao Z, Jian P, Safonova I, Price M (2017) Scientific Reports, Whole-mantle convection with tectonics plates preserves long-term global patterns of upper mantle geochemistry, 7, 1870, DOI:10.1038/s41598-017-01816-y

Day JM, Brandon AD, Walker RJ (2016) Highly siderophile elements in Earth, Mars, the Moon, and asteroids. Reviews in Mineralogy and Geochemistry, 81(1), pp.161-238.

Fischer-Gödde M, Elfers BM, Münker C, et al (2020) Ruthenium isotope vestige of Earth's pre-late-veneer mantle preserved in Archaean rocks. Nature 579:240-244. https://doi.org/10.1038/s41586-020-2069-3

Horan MF, Walker RJ, Morgan JW, Grossman JN, Rubin AE (2003) Highly siderophile elements in chondrites. Chemical Geology, 196(1-4), pp.27-42.

Maier WD, Barnes S-J (2004) Pt/Pd and Pd/Ir ratios in mantle-derived magmas: a possible role for mantle metasomatism. S Afr J Geol., 107, 333-340.

Maier WD, Barnes SJ, Campbell IH, Fiorentini ML, Peltonen P, Barnes S-J, Smithies RH (2009) Mantle magmas reveal progressive mixing of meteoritic veneer into the early Earth's deep mantle. Nature, 460, 620-623

Maier WD, Barnes S-J, Karykowski BT (2016) A chilled margin of komatiite and Mg-rich basaltic andesite in the western Bushveld Complex, South Africa. Contrib Mineral Petrol, DOI 10.1007/s00410-016-1257-5.

Mundl A, Touboul M, Jackson MG, Day JMD, Kurz MD, Lekic V, Helz RT, Walker RJ (2017), Tungsten-182 heterogeneity in modern ocean island basalts. Science 356, 66.

Naldrett AJ (2004) Magmatic sulfide deposits: Geology, geochemistry and exploration. Springer Science \& Business Media.

Puchtel IS, Mundl-Petermeier A, Horan MF, Hanski EJ, Blichert-Toft J, Walker RJ (2020) Ultra-depleted 2.05 Ga komatiites of Finnish Lapland: Products of grainy late accretion or core-mantle interaction? Chemical Geology 554, 119801.

Tusch J, Münker C, Hasenstab E, Jansen M, Marien CS, Kurzweil F, Van Krankendonk MJ, Smithies H, Maier WD, Garbe-Schönberg D (2021), Convective isolation of Hadean mantle reservoirs through Archean time. Proc Natl Acad Sci USA 118, e2012626118.

Walker RJ (2016) Siderophile elements in tracing planetary formation and evolution. Geochemical perspectives, $5(1)$, p.1. 